\title{
Assignment of vibrational spectra of labdatriene derivatives and ambers: a combined experimental and density functional theoretical study
}

\author{
Manuel Villanueva-García, Antonio Martínez-Richa, and Juvencio Robles* \\ Facultad de Química, Universidad de Guanajuato, Noria Alta S/N, \\ Guanajuato, Gto. , 36050 México \\ E-mail: roblesj@quijote.ugto.mx
}

This paper is dedicated to Eusebio Juaristi, a friend, teacher and model researcher

(received 22 Jun 05; accepted 25 Sept 05; published on the web 06 Oct 05)

\begin{abstract}
In this paper we present a theoretical study of the observed IR spectra of some samples of amber. We compare them to theoretically obtained spectra for a model of this natural polymer. The model assumes that communic acid and communol are plausible precursors in the natural polymerization of amber. We employ an electronic structure method at the BP86 density functional theory level. Our electronic structure methodology is found to be appropriate for the study and rationalization of the spectra of the chosen amber samples, with very good agreement with the observed spectra.
\end{abstract}

Keywords: Amber, FT-IR spectra, DFT, electronic structure calculations

\section{Introduction}

In recent years, significant advances achieved in different fields have enabled researchers to obtain more in-depth knowledge of material properties. In particular, the chemical characterization of fossil resins by modern analytical techniques has allowed the uncovering of the different chemical mechanisms operating within the plant before resins are formed. Analysis of fossil resins at different stages of maturation also aids in the elucidation of the chemical transformations occurring in the originally formed chemical structure over time. ${ }^{1}$

Amber is a fossilized tree resin that is mainly composed by a polylabdanoid fraction. This is largely insoluble in common organic solvents. The macromolecular component of amber is initially formed from the stereoespecific free-radical polymerization of 8(17), 12(13), 14(15) labdatriene precursors, mainly communic acid, communol and biformene (see Scheme 1) for the chemical structure of these monomers along with the accepted ring numbering). ${ }^{2,3,4}$ Maturation 
over the years induce further crosslinking, isomerization and cyclization reactions among others. ${ }^{5,6}$

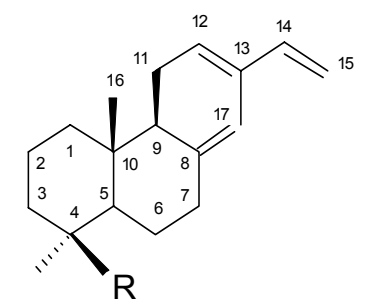

$$
\begin{aligned}
& \text { 1a Communic acid }(\mathrm{R}=\mathrm{COOH}) \\
& \text { 1b Communol }\left(\mathrm{R}=\mathrm{CH}_{2} \mathrm{OH}\right) \\
& \text { 1c Biformene }\left(\mathrm{R}=\mathrm{CH}_{3}\right)
\end{aligned}
$$

Scheme 1. Structure of monomers commonly found for amber polymerzations. (Usual numbering of atoms is employed)

Because amber is mostly an insoluble polymer of high molecular weight, chemical characterization of its components has relied in techniques such as solid-state FT-IR ${ }^{7,8}$ and NMR 9-11. Infrared spectroscopy is a rapid and reliable method to identify and characterize fossil resins. Application of this technique to the study of ambers is well documented, and nowadays it constitutes a basic technique in the characterization of these resins. Identification of functional groups has been done using band analysis based on empirical rules. However, to our knowledge there are no reports in the literature on the application of quantum mechanical methods to explain or rationalize spectral patterns observed in infrared (IR) bands or nuclear magnetic resonance (NMR) peaks of fossil resins. This means that the potentiality of the application of quantum mechanical tools in this field has not been explored yet.

The primary purpose of this study is to explain the origin of the vibrational bands observed in the infrared spectra of ambers using density functional theory (DFT) calculations. Geometry optimization for the communic acid monomer (Scheme 1, 1a) followed by derivation of the theoretical spectral pattern was performed and compared with the observed spectra of the amber samples. It was found that our theoretical calculations predict vibrational band positions with good accuracy. Also, a more complete image of the actual vibration modes operating during infrared absorption was obtained using this theoretical methodology.

\section{Results and Discussion}

Formation of hardened resins involves a polymerization process that preserved most of the functional groups present in the monomeric species with the exception of carbon-carbon double bonds. Thus, a similar band pattern is expected between the infrared spectra of amber and the labdatriene diterpene communic acid. The group of atoms present in communic acid gives rise to bands at or near to those frequencies observed for the polymer, due to their common chemical structure characteristics. 
The infrared spectra of four amber samples are shown in Figure 1. Observed bands along with band assignments are shown in Table 1. Several differences can be found in these spectra due to the amber samples different origin. Differences are more important in the hydroxyl group, carbonyl, carbon-oxygen single bond (1300 - $\left.1400 \mathrm{~cm}^{-1}\right)$ regions, and for the exocyclic methylene out-of-plane deformation band near $890 \mathrm{~cm}^{-1}$. In particular, the characteristic absorption pattern in the carbon-oxygen bond region (1250-1100 $\mathrm{cm}^{-1}$, due to esterified succinic acid) for the Baltic resin is present. Spectral features in this region have allowed discriminating between Baltic and non-Baltic resin samples. ${ }^{7}$

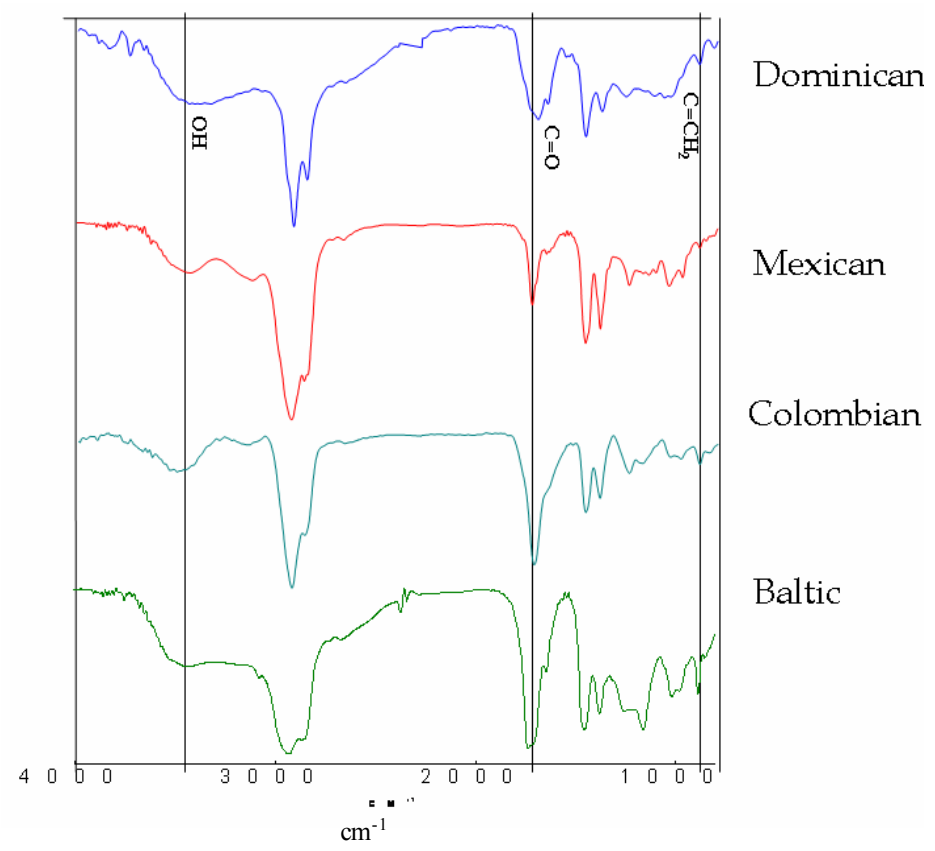

Figure 1. FT-IR spectra of four amber samples in the $400-800 \mathrm{~cm}^{-1}$ region.

Table 1. FT-IR bands (in $\mathrm{cm}^{-1}$ ) observed for amber samples

\begin{tabular}{lllllll}
\hline $\begin{array}{l}\text { Dominican } \\
\text { Amber A }\end{array}$ & $\begin{array}{l}\text { Dominican } \\
\text { Amber B }\end{array}$ & $\begin{array}{l}\text { Dominican } \\
\text { Amber C }\end{array}$ & $\begin{array}{l}\text { Colombian } \\
\text { Amber }\end{array}$ & $\begin{array}{l}\text { Baltic } \\
\text { Amber }\end{array}$ & $\begin{array}{l}\text { Mexican } \\
\text { Amber }\end{array}$ & $\begin{array}{l}\text { Band } \\
\text { Assignments }\end{array}$ \\
\hline 3419 & 3420 & 3441 & 3401 & 3458 & 3450 & $\mathrm{v}_{\mathrm{s}}(\mathrm{O}-\mathrm{H})$ \\
& & & 3079 & & & $\mathrm{v}_{\mathrm{s}}\left(\mathrm{CH}_{2}\right)$ \\
2933 & 2926 & 2922 & 2921 & 2929 & 2930 & $\mathrm{v}_{\mathrm{as}}\left(\mathrm{CH}_{2}\right)$ \\
2854 & 2867 & 2854 & 2852 & & & $\begin{array}{l}\text { Fermi doublet; } \\
\end{array}$ \\
& & & & & & $\mathrm{v}_{\mathrm{s}} \quad(\mathrm{H}-\mathrm{C}=\mathrm{O})$ \\
& & & & & with overtone \\
& 1716 & 1713 & & 1736 & 1725 & $\mathrm{v}_{\mathrm{s}}(\mathrm{C}=\mathrm{O})$ \\
1697 & 1653 & & 1694 & 1643 & 1650 & $\mathrm{v}_{\mathrm{s}}(\mathrm{C}=\mathrm{C})$ \\
\hline
\end{tabular}


Table 1. Continued

\begin{tabular}{|c|c|c|c|c|c|c|}
\hline 1458 & 1457 & 1458 & 1455 & 1455 & 1455 & $\begin{array}{l}\delta_{\mathrm{as}}\left(\mathrm{CH}_{3}\right) \\
\delta_{\mathrm{s}}\left(\mathrm{CH}_{2}\right)\end{array}$ \\
\hline 1376 & 1385 & 1379 & 1385 & 1380 & 1365 & $\begin{array}{l}\delta_{\mathrm{s}}\left(\mathrm{CH}_{3}\right) \\
\delta_{\mathrm{s}}(\mathrm{C}-\mathrm{O}-\mathrm{H}) \text { in- } \\
\text { plane bending }\end{array}$ \\
\hline 1256 & 1260 & 1253 & 1242 & 1250 & 1238 & $\mathrm{v}_{\mathrm{s}}(\mathrm{C}-\mathrm{O})$ \\
\hline \multirow[t]{2}{*}{1064} & 1120 & 1121 & 1172 & 1166 & 1145 & $\mathrm{v}_{\mathrm{s}}(\mathrm{C}-\mathrm{C})$ \\
\hline & 1070 & 1069 & $\begin{array}{l}1127 \\
1044 \\
976 \\
945\end{array}$ & $\begin{array}{l}1019 \\
909\end{array}$ & 1030 & $\begin{array}{l}v_{\text {s }}(\mathrm{C}-\mathrm{O}) \text { in } \\
\text { alcohols } \\
\delta_{\text {as }}(=\mathrm{C}-\mathrm{H}) \text { out- } \\
\text { of-plane } \\
\text { deformation }\end{array}$ \\
\hline \multirow[t]{5}{*}{888} & 888 & 889 & 889 & & & $\begin{array}{l}\omega\left(\mathrm{C}=\mathrm{CH}_{2}\right), \\
\text { out-of-plane } \\
\text { wagging }\end{array}$ \\
\hline & 805 & 816 & 794 & & 797 & $\rho(\mathrm{C}-\mathrm{H})$ \\
\hline & & & 740 & 721 & & \\
\hline & & & 699 & 699 & & \\
\hline & 668 & & 667 & & & \\
\hline
\end{tabular}

Based on the observed band pattern, it is more likely that Mexican amber is older than the others $^{16}$. In the spectrum for this sample, the band for out-of-plane deformation of end groups $=\mathrm{CH}_{2}$ is almost absent. Other differences are observed in the shapes and positions of hydroxyl, carbonyl and $\mathrm{C}-\mathrm{O}$ bands. All these differences indicate that oxidation and further polymerization due to maturation have occurred in a higher extent for the Mexican amber sample.

\section{Theoretical vibrational frequencies}

Density functional theory ${ }^{17}$ calculations include terms for electronic correlation, and thus allow the prediction of vibrational frequencies with higher degree of accuracy than $a b$ initio HartreeFock calculations. However, overestimation of band frequencies is still observed. When calculations are done at the DFT BP86/DN* level, it has been reported that a scale factor 0.9914 can be used to fit the predicted band frequencies to the experimental value. ${ }^{18}$ Therefore hereby our results are adjusted by this scaling factor.

In Figures 2 and 3, the optimized geometry for communic acid at the DFT BP86/DN* level is shown. The results for communol are essentially identical, except for the region around the hydroxyl group. Since the rest of the molecule, specifically the region around the double bonds is quite similar in both acid and alcohol, we will concentrate the discussion only on the communic acid results from hereafter. 


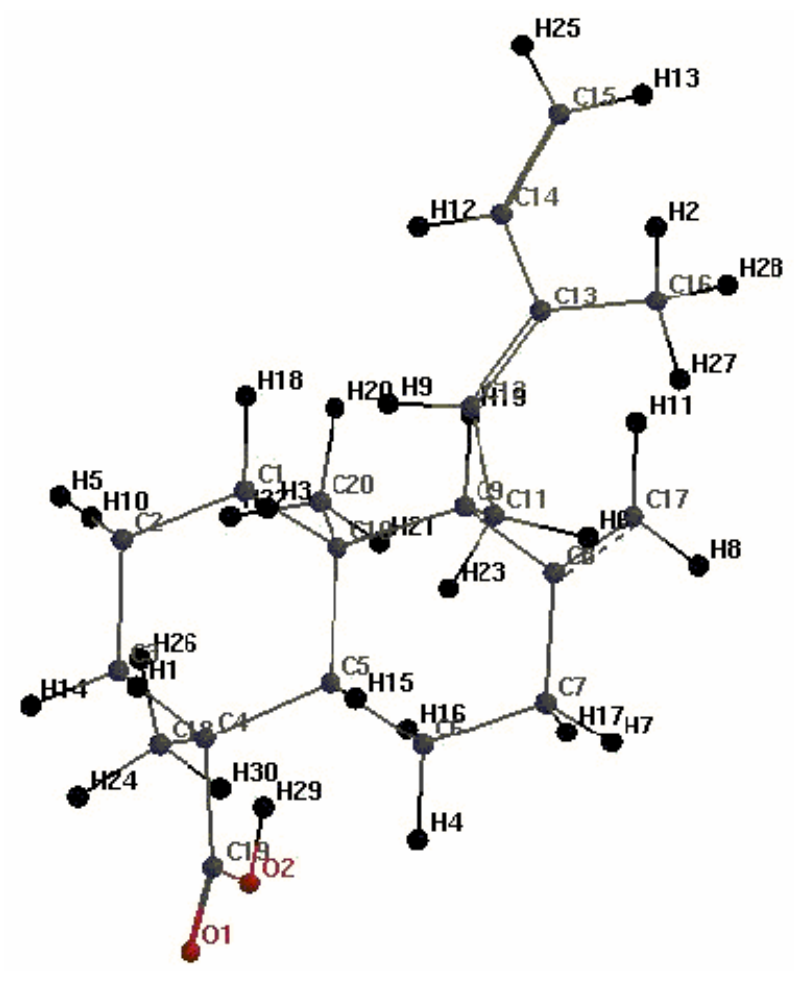

Figure 2. Optimized geometry for communic acid at the DFT BP86/DN* level.

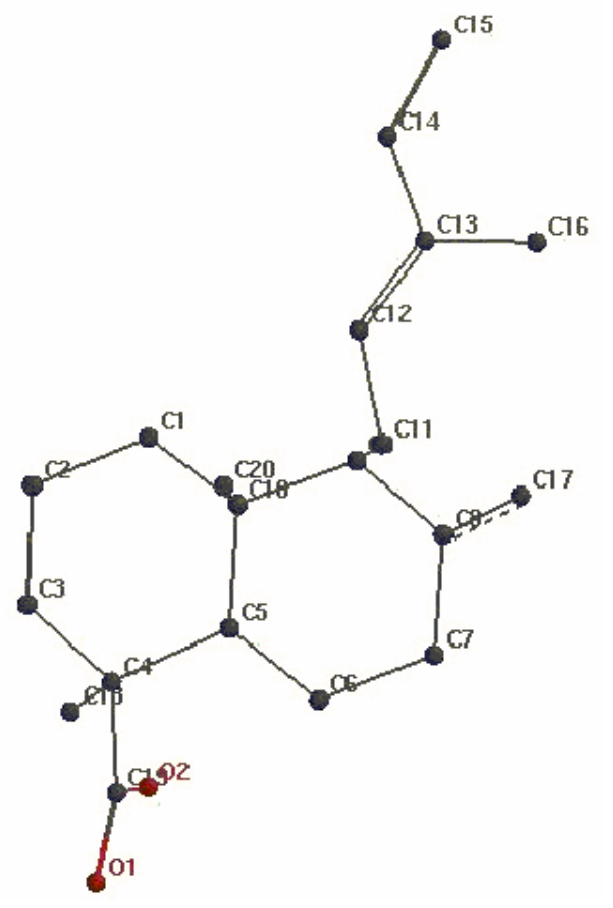

Figure 3. Optimized geometry for communic acid at the DFT BP86/DN* level. 
In Table 2, experimental band wavenumbers and their assignments for different ambers are shown. Calculated wavenumbers for communic acid (corrected with the abovementioned scale factor) are also shown in parenthesis. In the last row, the absolute average error is reported. These values indicate that the calculated wavenumbers obtained at our chosen DFT level have a numerical precision that is overall satisfactory.

Table 2. Observed and calculated vibrational frequencies (in $\mathrm{cm}^{-1}$ ). (a) Experimental vibrational frequencies in $\mathrm{cm}^{-1}$. (b) The quantities in parenthesis correspond to the theoretical frequencies at the $\mathrm{BP} 86 / \mathrm{DN}^{*}$ level (the numerical basis $\mathrm{DN}^{*}$ is comparable in size with the $6-31 \mathrm{G}^{*}$ basis). (c) $\%$ Absolute error average.

\begin{tabular}{|c|c|c|c|c|c|c|}
\hline $\begin{array}{l}\text { Dominican } \\
\text { Amber A }\end{array}$ & $\begin{array}{l}\text { Dominican } \\
\text { Amber B }\end{array}$ & $\begin{array}{l}\text { Dominican } \\
\text { Amber C }\end{array}$ & $\begin{array}{l}\text { Colombian } \\
\text { Amber }\end{array}$ & $\begin{array}{l}\text { Baltic } \\
\text { Amber }\end{array}$ & $\begin{array}{l}\text { Mexican } \\
\text { Amber }\end{array}$ & $\begin{array}{l}\text { Band } \\
\text { Assignments }\end{array}$ \\
\hline $\begin{array}{l}3419^{\mathrm{a}} \\
(3541)^{\mathrm{b}}\end{array}$ & $\begin{array}{l}3420 \\
(3541)\end{array}$ & $\begin{array}{l}3441 \\
(3541)\end{array}$ & $\begin{array}{l}3401 \\
(3541)\end{array}$ & $\begin{array}{l}3458 \\
(3541)\end{array}$ & $\begin{array}{l}3450 \\
(3541)\end{array}$ & $\mathrm{v}_{\mathrm{s}}(\mathrm{O}-\mathrm{H})$ \\
\hline $\begin{array}{l}2933 \\
(2931)\end{array}$ & $\begin{array}{l}2926 \\
(2926)\end{array}$ & $\begin{array}{l}2922 \\
(2922)\end{array}$ & $\begin{array}{l}3079 \\
(3064)\end{array}$ & $\begin{array}{l}2929 \\
(2927)\end{array}$ & $\begin{array}{l}2930 \\
(2931)\end{array}$ & $\mathrm{v}_{\mathrm{s}}\left(\mathrm{CH}_{2}\right)$ \\
\hline & & & $\begin{array}{l}2921 \\
(2921)\end{array}$ & & & $\mathrm{v}_{\mathrm{as}}\left(\mathrm{CH}_{2}\right)$ \\
\hline $\begin{array}{l}2854 \\
(2886)\end{array}$ & $\begin{array}{l}2867 \\
(2886)\end{array}$ & $\begin{array}{l}2854 \\
(2886)\end{array}$ & $\begin{array}{l}2852 \\
(2886)\end{array}$ & & & $\begin{array}{l}\text { Fermi doublet; } \\
(\mathrm{H}-\mathrm{C}=\mathrm{O}) \\
\text { overtone of } \delta\left(\mathrm{CH}_{2}\right)\end{array}$ \\
\hline (1756) & $\begin{array}{l}1716 \\
(1756)\end{array}$ & $\begin{array}{l}1713 \\
(1756)\end{array}$ & & $\begin{array}{l}1736 \\
(1756)\end{array}$ & $\begin{array}{l}1725 \\
(1756)\end{array}$ & $\mathrm{v}_{\mathrm{s}}(\mathrm{C}=\mathrm{O})$ \\
\hline $\begin{array}{l}1697 \\
(1648)\end{array}$ & $\begin{array}{l}1653 \\
(1648)\end{array}$ & & $\begin{array}{l}1694 \\
(1648)\end{array}$ & $\begin{array}{l}1643 \\
(1648)\end{array}$ & $\begin{array}{l}1650 \\
(1648)\end{array}$ & $\mathrm{v}_{\mathrm{s}}(\mathrm{C}=\mathrm{C})$ \\
\hline $\begin{array}{l}1458 \\
(1459)\end{array}$ & $\begin{array}{l}1457 \\
(1459)\end{array}$ & $\begin{array}{l}1458 \\
(1459)\end{array}$ & $\begin{array}{l}1455 \\
(1455)\end{array}$ & $\begin{array}{l}1455 \\
(1455)\end{array}$ & $\begin{array}{l}1455 \\
(1455)\end{array}$ & $\begin{array}{l}\delta_{\mathrm{as}}\left(\mathrm{CH}_{3}\right) \\
\delta_{\mathrm{s}}\left(\mathrm{CH}_{2}\right)\end{array}$ \\
\hline $\begin{array}{l}1376 \\
(1383)\end{array}$ & $\begin{array}{l}1385 \\
(1383)\end{array}$ & $\begin{array}{l}1379 \\
(1383)\end{array}$ & $\begin{array}{l}1385 \\
(1383)\end{array}$ & $\begin{array}{l}1380 \\
(1383)\end{array}$ & $\begin{array}{l}1365 \\
(1359)\end{array}$ & $\begin{array}{l}\delta_{\mathrm{s}}\left(\mathrm{CH}_{3}\right) \\
\delta_{\mathrm{s}} \quad(\mathrm{C}-\mathrm{O}-\mathrm{H}) \quad \text { in- } \\
\text { plane bending }\end{array}$ \\
\hline $\begin{array}{l}1256 \\
(1250)\end{array}$ & $\begin{array}{l}1260 \\
(1265)\end{array}$ & $\begin{array}{l}1253 \\
(1250)\end{array}$ & $\begin{array}{l}1242 \\
(1250)\end{array}$ & $\begin{array}{l}1250 \\
(1246)\end{array}$ & $\begin{array}{l}1238 \\
(1237)\end{array}$ & $\mathrm{v}_{\mathrm{s}}(\mathrm{C}-\mathrm{O})$ \\
\hline & $\begin{array}{l}1120 \\
(1120)\end{array}$ & $\begin{array}{l}1121 \\
(1120)\end{array}$ & $\begin{array}{l}1172 \\
(1080)\end{array}$ & $\begin{array}{l}1166 \\
(1160)\end{array}$ & $\begin{array}{l}1145 \\
(1133)\end{array}$ & $\begin{array}{l}v_{\mathrm{s}}(\mathrm{C}-\mathrm{C}) \\
\mathrm{v}^{\mathrm{s}} \quad(\mathrm{C}-\mathrm{O})\end{array}$ \\
\hline $\begin{array}{l}1064 \\
(1061)\end{array}$ & $\begin{array}{l}1070 \\
(1071)\end{array}$ & $\begin{array}{l}1069 \\
(1071)\end{array}$ & $\begin{array}{l}1127 \\
(1127) \\
1044 \\
(1038)\end{array}$ & $\begin{array}{l}1019 \\
(1019)\end{array}$ & $\begin{array}{l}1030 \\
(1031)\end{array}$ & alcohols \\
\hline
\end{tabular}


Table 2. Continued

\begin{tabular}{|c|c|c|c|c|c|c|}
\hline & & & $\begin{array}{l}976 \\
(977)\end{array}$ & $\begin{array}{l}909 \\
(906)\end{array}$ & & $\begin{array}{l}\delta_{\mathrm{as}}(=\mathrm{C}-\mathrm{H}) \text { out-of- } \\
\text { plane deformation }\end{array}$ \\
\hline & & & $\begin{array}{l}945 \\
(950)\end{array}$ & & & \\
\hline \multirow{10}{*}{$\begin{array}{l}888 \\
(889)\end{array}$} & 888 & 889 & 889 & & & $\omega\left(\mathrm{C}=\mathrm{CH}_{2}\right)$, out-of- \\
\hline & (889) & (889) & $(889)$ & & & plane wagging \\
\hline & 805 & 816 & 794 & 721 & 797 & $\rho(\mathrm{C}-\mathrm{H})$ \\
\hline & $(803)$ & $(826)$ & (787) & (717) & $(802)$ & \\
\hline & 668 & & 740 & 699 & & \\
\hline & $(666)$ & & (744) & $(701)$ & & \\
\hline & & & 699 & & & \\
\hline & & & $(702)$ & & & \\
\hline & & & 667 & & & \\
\hline & & & $(666)$ & & & \\
\hline $1.01 \%{ }^{\mathrm{c}}$ & $0.64 \%$ & $0.79 \%$ & $1.13 \%$ & 0.51 & $0.69 \%$ & \\
\hline
\end{tabular}

\section{Vibrational modes in labdanes}

In Figure 4, some selected normal modes obtained theoretically are depicted. A more detailed picture for the vibrations performed by the labdane skeleton can be visualized. It is well known that when two oscillators share a common atom, coupling between individual oscillators is expected. ${ }^{19}$ In that regard, the O-H stretching band (due mainly to the vibration of the hydroxyl group) has some influence of the stretching-vibration performed by the $C(19)-O(2)$ bond. Similarly, the band due to $\mathrm{C}=\mathrm{O}$ is coupled to the in-plane bending vibrations performed by $\mathrm{C}(19)$ $-\mathrm{O}(2)-\mathrm{H}(29)$. The absorption band at around $800 \mathrm{~cm}^{-1}$ is mainly due to the methylene bending $\mathrm{H}-\mathrm{C}(7)-\mathrm{H}$ vibration, and band at $1365 \mathrm{~cm}^{-1}$ is mainly due to the symmetrical bending of the methine $\mathrm{C}(5)-\mathrm{H}$ bond. However, influence of the bending methyl C-H bonds is also expected ${ }^{18}$. Bands in the region 1020-1160 $\mathrm{cm}^{-1}$ are mainly due to carbon-carbon stretching vibrations, and according to our theoretical results the $\mathrm{C} 1-\mathrm{C} 10$ bond vibration and the asymmetrical $\mathrm{H}-\mathrm{C}(16)-\mathrm{H}$ methyl stretching vibration have the most important contributions. Absorption at $c a .800 \mathrm{~cm}^{-1}$ are attributed to the $\mathrm{H}-\mathrm{C}(7)-\mathrm{H}$ vibrational mode shown in Figure 4. Finally, the in-plane rocking vibration ( $\rho \mathrm{H}-\mathrm{C}(7)-\mathrm{H})$ mode of the exocyclic methylene, observed at $c a .720 \mathrm{~cm}^{-1}$, is coupled to the stretching vibration of the $\mathrm{C}(8)=\mathrm{C}(17)$ double bond. 


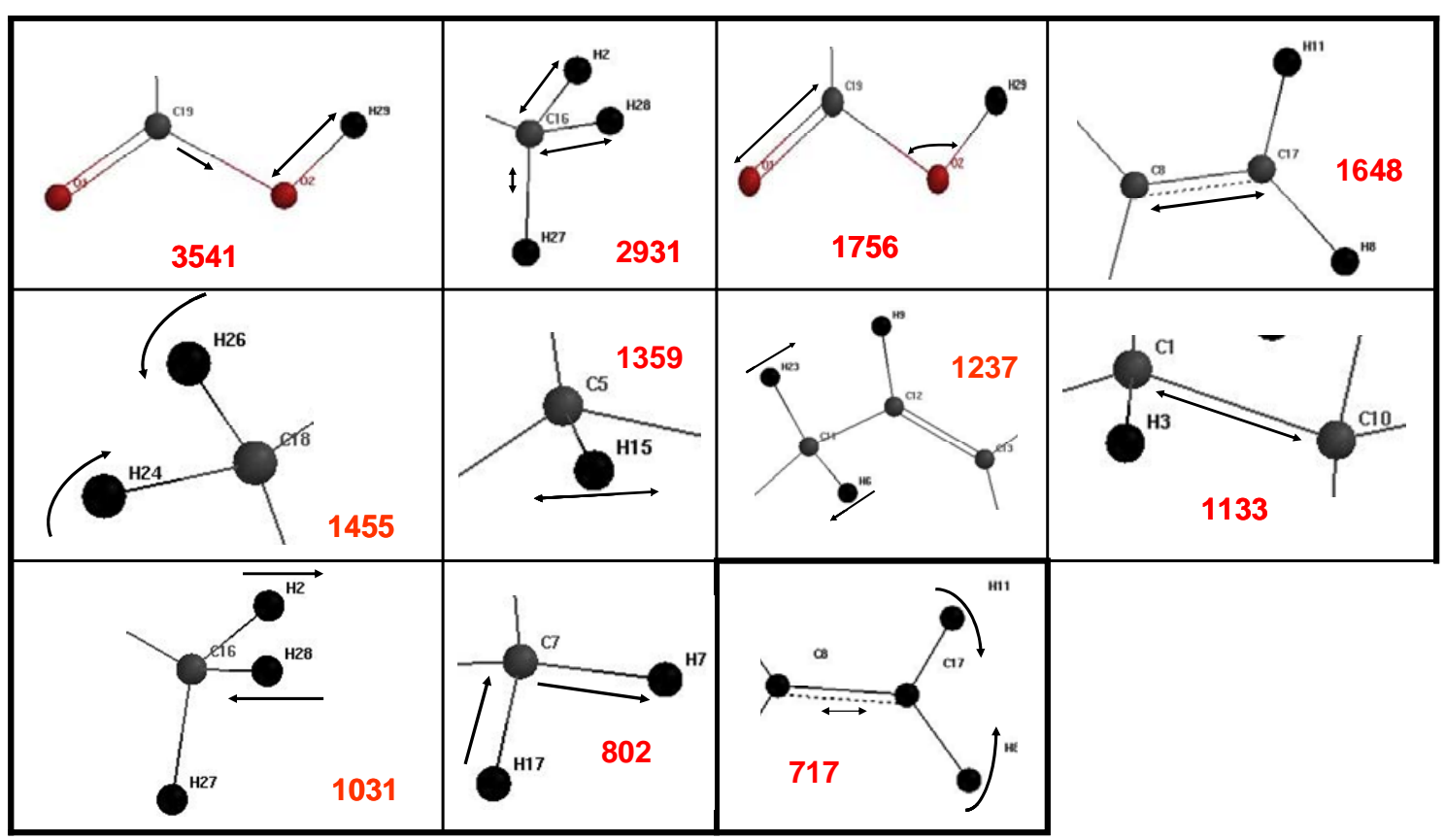

Figure 4. Selected vibrational modes and band positions for different functional groups present in communic acid.

\section{Conclusions}

Our electronic structure methodology at the BP86/DN* DFT level of calculation, is found to be appropriate for the study and rationalization of the spectra of the chosen amber samples, with very good agreement with the observed spectra. In particular, coupling between different vibrational modes involved in the observance of some bands is properly disclosed by means of molecular simulation. This method allows an unambiguous band assignment of the complex band pattern observed in the IR spectra of amber samples, and can be extended to the study of other labdane derivatives.

\section{Experimental Section}

\section{General Procedures}

Experimental. Original amber samples from Colombia (copalite from the Cimitarra quadrangle $^{11}$, Dominican Republic (three samples), Chiapas (Mexico) and Baltic region were grounded before being analyzed. Fourier transform infrared spectra (FT-IR) of 6 resins using in this study were recorded from $\mathrm{KBr}$ pellets in the $4000-600 \mathrm{~cm}^{-1}$ range using a Perkin Elmer FT 1600 spectrometer operating at a resolution of $4 \mathrm{~cm}^{-1}$. Typically, 64 interferograms were collected. 
Theoretical. Vibrational frequencies for communic acid were derived using electronic structure methods. A full geometry optimization of communic acid and communol monomers with no symmetry restrictions was performed at the DFT BP86/DN* level of theory. The BP86 functional employs the gradient-corrected exchange-functional proposed by Becke ${ }^{12}$ (1988) and the correlation functional by Perdew ${ }^{13}$ (1986) in the calculation of total energy and gradients. $\mathrm{DN}^{*}$ is a double-zeta numerical basis set and is comparable in size with the Gaussian $6-31 \mathrm{G}^{*}$ basis $^{14}$. Once the lowest energy structure was obtained, vibrational frequencies were computed from calculation of the Hessian. All frequencies were positive at our DFT level of calculation. Therefore we are certain that a true absolute minimum in the potential energy surface was found. For the electronic calculations, we prepared the initial molecular coordinates, performed the calculations and visualized results employing the Spartan 5.1.1 software package ${ }^{15}$. The

calculations were performed on a SGI Octane Workstation and a SGI Origin Series 2000 computer.

\section{Acknowledgements}

We are indebted with Francisco Segoviano for obtaining the FT-IR spectra of the amber samples. JR and AM-R are grateful to Departamento de Supercómputo (DGSCA-UNAM) for providing us accounts in a SGI Origin Series 2000 computer. Financial support from CONACYT through project SEP-2003-C02-43453 and from Universidad de Guanajuato is acknowledged.

\section{References and Footnotes}

1. Amber, Resinite and Fossil Resins; Anderson, K.B.; Crelling, J.C. Eds.; ACS Symposium Series, 1995; p 617.

2. Cunningham, A.; Gay, I.D.; Oehlschlager, A.C.; Langenheim, J.H. Phytochemistry 1993, 22, 965.

3. Ember, L. Chem. Eng. News 1997, 77, 13.

4. Robles, J.; Martínez-Richa, A.; Villanueva, M. Comp. and Theoretical Polym. Sci. 2000, 10, 473

5. Anderson, K.B.; Botto, R.E. Org. Geochem. 1993, 20, 1027.

6. Clifford, D.J.; Hatcher, P.G. in ref. 1, p 92.

7. Beck, C.W. Appl. Spectrosc. Rev. 1986, 22, 57.

8. Stout, E.C.; Beck C.W.; Kosmokowska-Ceranowicz, B. in ref. 1, p 130.

9. Lambert, J.B.; Frye, J.S. Science 1982, 217, 55.

10. Lambert, J.B.; Frye, J.S.; Poinar, G.O. Archaeometry 1985, 27, 43.

11. Martinez-Richa, A.; Vera-Graziano, R.; Rivera, A.; Joseph-Nathan, P. Polymer 2000, 41, 743. 
12. Becke, A.D. J. Phys Rev. A 1988, 38, 3098.

13. Perdew, J.P. Phys Rev. B 1986, 33, 8822.

14. Warren, J. H.; Liang, Lou. A Guide to Density Functional Calculations in SPARTAN, Wavefunction Inc., 18401 Von Karman Ave., Suite 370, Irvine, CA, USA, 1997.

15. Spartan, version 5.1.1., Wavefunction Inc., 18401 Von Karman Ave., Suite 370, Irvine, CA, USA, 1999.

16. Langenheim, J. H. Science 1969, 163, 1157.

17. Parr, R. G.; Yang, W. Density-Functional Theory of Atoms and Molecules; Oxford University Press: U.S.A., 1989.

18. Scott, A. P.; Radom, L. J. Phys. Chem. 1996, 100, 16502.

19. Silverstein, R. M.; Bassler, G. C.; Morril, T.C. Spectrometric Identification of Organic Compounds; Wiley: USA, 1991; p 94. 